\title{
Bookshelf 2019
}

\author{
Richard Price and Sally Price \\ Coquina Key, Florida, UsA \\ rixsal@gmail.com;www.richandsally.net
}

This year, once again, we begin by expressing our gratitude to all the reviewers who have, collectively, provided such a rich resource for keeping up with writing on the region. At the same time, we must lament the fact that some of the people who've accepted a book and promised to review it have, despite gentle reminders over a year or two, never shared their assessment with NWIG readers. With apologies to the authors of books that have therefore not been given their due in these pages, we simply list them here.

Colonial Phantoms: Belonging and Refusal in the Dominican Americas, from the 19th Century to the Present, by Dixa Ramírez (New York: NYU Press, 2018, paper US\$30.00) (Six scholars declined to review this book before one said yes. After sending three reminders to that person, we finally gave up hope.)

Voices from Mariel: Oral Histories of the 1980 Cuban Boatlift, by José Manuel García (Gainesville: University Press of Florida, 2018, cloth US\$24.95)

Island Historical Ecology: Socionatural Landscapes of the Eastern and Southern Caribbean, edited by Peter E. Siegel (New York: Berghahn, 2018, cloth US\$130.00)

Beyond Cuban Waters: Africa, La Yuma, and the Island's Global Imagination, by Paul Ryer (Nashville TN: Vanderbilt University Press, 2016, paper US\$27.95)

Crime, Violence, and Security in the Caribbean, edited by M. Raymond Izarali (London: Routledge, 2017, cloth US\$145.00)

Practices of Resistance in the Caribbean: Narratives, Aesthetics, and Politics, edited by Wiebke Beushausen, Miriam Brandel, Joseph T. Farquharson, Marius Littschwager, Annika McPherson \& Julia Roth (London: Routledge, 2018, cloth US\$149.95)

Borderline Citizens: The United States, Puerto Rico, and the Politics of Colonial Migration, by Robert C. McGreevey (Ithaca NY: Cornell University Press, 2018, cloth US\$ 45.0o) Population, Migration, and Socioeconomic Outcomes among Island and Mainland Puerto Ricans: La Crisis Boricua, by Marie T. Mora, Alberto Dávila \& Havidán Rodríguez (Lanham MD: Lexington Books, 2017, cloth US\$95.00)

African Kings and Black Slaves: Sovereignty and Dispossession in the Early Modern Atlantic, by Herman L. Bennett (Philadelphia: University of Pennsylvania Press, 2018, cloth US\$24.95) 
We asked seven reviewers to tackle the following two books together but none were willing, so we merely list the titles: Patriot or Traitor: The Life and Death of Sir Walter Ralegh, by Anna Bee (London: Oneworld Publications, 2018, cloth US\$27.95), and Walter Ralegh: Architect of Empire, by Alan Gallay (New York: Basic Books, 2019, cloth US\$ 40.00).

After reading Crossroads of Colonial Cultures: Caribbean Literatures in the Age of Revolution, by Gesine Müller (Berlin: Mouton De Gruyter, 2018, paper US\$ 45.99), our reviewer wrote that she found it impossible to review the book because it was "very disorganized and also lacking in coherence, such that whatever merits there may be in its many arguments were difficult to judge." We regret not being able to publish a review.

Our readers may also be interested in the following exchange, concerning Decolonial Puerto Rican Women's Writings: Subversion in this Flesh, by Roberta Hurtado (Basingstoke, U.K.: Palgrave Macmillan, 2019, cloth US\$ 74.99), which speaks to the state of publishing these days. The Book Review Coordinator of Springer Nature (which now handles book review requests for Palgrave Macmillan, a major publisher on the Caribbean) wrote to our reviewer offering to provide an eBook instead of a print copy since, she said, in order to implement a more sustainable and environmentally friendly system, they were promoting the use of digital copies of their books wherever possible. The reviewer replied, "I have carpal and cubital tunnel in both hands and therefore, an eBook will be very hard to handle. I really understand the importance of promoting environmental friendly policies, but due to my medical condition I really hope we can make an exception and work something out." Springer's coordinator wrote back: "Thank you for your e-mail and I am sorry for your health problems. Unfortunately, I can't make an exception in this case."

If this policy continues, we may well need to stop providing reviews of Palgrave books for the several thousand readers of the NWIG. How short-sighted on the part of Springer/Palgrave and what a shame for Caribbeanists! One needn't be overly cynical to wonder whether environmental concerns might be a less important motivation for Palgrave than the cost of sending review copies through the mail. (Several other European publishers have begun to give reviewers a choice between receiving a PDF or a book, not citing the environment but rather the high price of international book mailing.)

We next list books that we requested for review in Bookshelf but which the publisher, for whatever reason, did not send.

Kazal: Memories of a Massacre under Duvalier - a Photographic Approach, by KOLE KTIF2D, edited under the direction of Nicola Lo Calzo (Roquevaire, France: André Frère Éditions, 2019, cloth € 29.00) 
The Defining Sea, by Robert Friedman (Mechanicsburg PA: Brown Posey Press, 2019, paper US\$14.95)

An Inquiry into Choteo, by Jorge Mañach, translated and with an introduction by Jacqueline Loss (Barcelona: Linkgua Ediciones, 2019, paper US\$14.0o)

On Being Committed to a Small Place, by Annalee Davis (San José, Costa Rica: TEOR/ éTica, 2019, paper US\$20.00)

Girl, Woman, Other, by Bernadine Evaristo (London: Hamish, Hamilton, 2019, paper US\$17.00) [Winner of the Booker Prize]

Unraveling, by Karen Lord (New York: DAW, 2019, cloth US\$26.oo)

The Golden Hour: A Novel, by Beatriz Williams (New York: William Morrow, 2019, cloth, US\$26.99)

Waiting for the Revolution, Cuba: The Unfinished Journey, by Gustavo Gac-Artigas (New Jersey: Ediciones Nuevo Espacio, 2019, paper US\$9.99)

When the Sky Fell: Hurricane Maria and the United States in Puerto Rico, by Michael Deibert (New York: Apollo Publishers, 2019, cloth US\$24.99)

My Time Among the Whites: Notes from an Unfinished Education, by Jennine Capó Crucet (New York: Picador, 2019, paper US\$17.00)

Black Leopard, Red Wolf (The Dark Star Trilogy Book 1), by Marlon James (New York: Riverhead, 2019, cloth US\$30.0o)

Grab a Snake by the Tail:A Murder in Havana's Chinatown, by Leonardo Padura (London: Bitter Lemon, 2019, paper US\$14.95)

Le théâtre d'Aimé Césaire, by Gérard Cogez (Lausanne: Ides et Calendes, 2018, paper $€ 10.00)$

We begin our mini-reviews, as usual, with novels.

Around Harvard Square, by Jamaica-born novelist and journalist C.J. Farley (Brooklyn NY: Akashic, 2019, paper US\$14.95) explores issues of race and class among a small cluster of Ivy-League freshmen as they learn the intricacies of Cambridge life in the 1990s. An African American student-athlete, an Asian American who sells dope, a child-star Bollywood actress, and a girl from rural Jamaica are swept up in the world of final clubs, the Crimson, and the Lampoon, all the while finding out who they are. It's chock-full of (unreferenced) bits and pieces of literary works (from Sylvia Plath to Claude McKay), esoterica of Harvard history (a conversation about Pickering's Harem), and more-not every reader will pick up on the same set (though some, such as the discussion of Willie DuBois and the theory of double unconsciousness, will be easy for any $N W I G$ reader). For anyone who likes satire, this quick-witted tale, which sometimes borders on action-comix narration, catches a bundle of truths about a very particular and powerful corner of our world. 
Patsy (New York: Liveright, 2019, cloth US\$26.95), Jamaican Brooklynite Nicole Dennis-Benn's second novel, is, like her earlier Here comes the Sun, a page-turner that explores the lives of women who love women, anxieties about race, color, and sexuality (this time in New York as well as Jamaica), and family relations, especially between mothers and daughters. Patsy immigrates (guiltily leaving her daughter behind) and works (without papers) as a bathroom attendant in a faux-Jamaican restaurant and as a nanny, while her daughter, brought up in her father's household, navigates adolescence and heartbreak in Kingston. In its depiction of the rough and lonely life of undocumented aliens in New York, it brings to mind Évelyne Trouillot's Absences sans frontiers (2013), in which it is a father who devotes his life to working at mean jobs so his daughter back home can have a brighter future, but here it is the guilt of separation and abandonment that dominates. As we noted about DennisBenn's debut novel, Patsy neatly captures the complex pathos of contemporary Caribbean realities.

Curdella Forbes's haunting, intriguing, and absorbing fifth novel, $A$ Tall History of Sugar (Brooklyn NY: Akashic, 2019, cloth US\$28.95), takes us from the rural Jamaica of the 195 os to Kingston to Brixton and back, tracing the love story of a strange-looking pale-skinned boy, found as a baby in a basket by the sea, and the book's narrator, a beautiful black girl who grows into a political activist. Fairy-tale or myth-like, with colonialism, race, sugar, and slavery always in the background, the story unfolds with frequent use of Jamaican Creole and allusions to Caribbean literature. A memorable read.

Drafts of a Suicide Note (Raleigh NC: Regal House Publishing, 2019, paper US\$19.95), by Mandy-Suzanne Wong (according to the publisher's website, "a born Bermudian of Jamaican parentage and confusing Afro-Chino-Cuban heritage"), is a long and dark debut novel centered on a mysterious woman who disappeared, leaving ten cryptic suicide notes. The main protagonists are elite Bermudans involved in the murky world of risk management, wealth management, reinsurance, document shredding, and designer drugs, but it's also a story of love, mistrust, obsession, and betrayal. The author clearly has a love of literature as well as a lively imagination, and she weaves a memorable, complex tale.

Queen of Bones (A Havana Mystery), by Teresa Dovalpage (New York: Soho, 2019, cloth US\$26.95), is fast-paced crime fiction by a Cuban-born, New Mexico-resident writer, who loads lots of local color into her plot twists. Santeros, detectives, and mortuary employees mix with cross-dressers and American tourists in this telenovela-like tale.

Plastered in Pretty (Philipsburg, St. Maarten: House of Nehesi, 2018, paper US\$20.00), a novella by Vincentian writer and teacher Natasha C. Marks, 
describes an island world in which social media rules and where people look up from their cellphones only for the briefest of sexual or workplace encounters and are obsessed with online buying, posing, selfies, and seeking digital nirvana in the form of "likes" and happy emojis. The genre is satire and the tone chicklit, but it depicts a Caribbean dystopia, sometimes comic, yet disturbingly close enough to a possible near future to foster thought and unease.

Dominicana (New York: Flatiron, 2019, paper US\$26.99), Angie Cruz's third novel, is based on her mother's coming-of-age experience as a fifteen-year-old country girl whose parents marry her off to a much older businessman, who quickly whisks her away to the Washington Heights of the 196os. Unflinching in its portrayal of marital violence and patriarchal norms, it paints a thoroughly believable picture of Dominican immigrant life, both growing up surrounded by canefields and living in a squeezed apartment across from the Audibon Ballroom. Relationships and events grab you and stir the emotions; it's hard to put down.

On its initial publication in Cuba, Marcial Gala's La catedral de los negros (2012) was awarded the Alejo Carpentier Prize and the Premio de la Crítica Literaria. Now published as The Black Cathedral (New York: Farrar, Straus \& Giroux, 2020, cloth US\$26.00) in a fine translation by Anna Kushner, it is indeed a memorable work, narrated in a series of one- or two-page first-person fragments by a myriad of colorful inhabitants of a run-down neighborhood of Cienfuegos. Painting, architecture, and poetry rub shoulders with a serial killer, cannibalism, sex, violence, racism, and love, as provincial Cubans stay in place (or prison), flee to the United States and Barcelona, and deal with a never-finished overblown Protestant cathedral. The writing is finely honed, sometimes darkly comic, as the protagonists pick up and interrupt each other's stories. A dystopian yet heart-rending vision not only of contemporary Cuba but also of the disappointments of the Obama-era United Sates of America.

Two novels of questionable origin. The latest iteration of William Williams's The Journal of Penrose, Seaman (newly subtitled: The New Robinson Crusoe and the First American Novel), edited by Welsh author Terry Breverton (Carmarthenshire, Wales: Cambria Books, 2014, paper $£ 20.00$ ), is a modernized version of the ca. 1775 manuscript, which was first published in a bowdlerized edition in 1815 and then in a full transcription in 1969 (by Indiana U.P.), relating the author's (alleged) experience of being marooned on the Miskito coast among the Rama Indians. Joining it is the probably fictional/forged Hayti (Carmarthenshire, Wales: Cambria Books, 2017, paper US\$17.99), with the author listed as Kurtis Sunday (a living novelist) and a preface claiming that this "is probably the first work of fiction written in a European language in the New 
World," and that the original manuscript was discovered in Granada in 1904 (or, alternatively, in France ca. 180o) and then destroyed during the Spanish Civil War, but meanwhile published in 1924 in Barcelona in Catalan, then in 1939 in London in English, and finally in 1969 in Mexico in Spanish. (The "translator" claims to have relied on all editions.) The apparently fictional text is said to have been written by a Hieronymite nun named Lucrezia di Marchionni and depicts Spanish atrocities, conversations with the Tainos, maroon resistance, and other happenings around 1515 .

Raphaël Confiant has added a 350-page thriller to his dozens of published books: L'enlèvement du mardi-gras, enquête sur une disparition (Paris: Éditions Écriture, 2019, paper $€ 20.00$ ). At once ostentatiously vulgar and ironic, this comic roman à clef centers on Martiniquan university life, with corrupt and inept police vying with corrupt and inept faculty and elected officials. With his usual joyful vengeance, Confiant takes on what he sees as the underbelly of Martinique and its inhabitants, reveling in the everyday racism and concupiscence, the greed and selfishness, the violence and humor. You either put it down quickly (our tendency) or, perhaps, you laugh along with the clever but often facile turns of phrase.

Tercer Mundo (San Juan: Zemi Books, 2019, paper US\$24.95), by prolific Puerto Rican novelist/science fiction writer Pedro Cabiya (who lives in the Dominican Republic), begins with the crash in Santurce of a spaceship containing treasure. Mixing genres and registers, it explores the shenanigans of the bureaucrats who administer "la República Borikwá" and compete to get ahold of it, creating a phantasmagoric counterpart to current Puerto Rican political and existential realties.

The Restless, by Gerty Dambury (New York: The Feminist Press at CUNY, 2018, paper US\$16.95) - Judith G. Miller's excellent translation of the 2014 French original, Les rétifs - tells the story of the 1967 labor violence in Guadeloupe, where the French forces de l'ordre killed or seriously wounded more than 100 protesters and bystanders. Narrated in syncopated first-person chapters in the form of a Caribbean quadrille, with a nine-year-old girl whose schoolteacher (accused of being a subversive) has disappeared leading the way, most of the other tale-tellers are already dead and include Queen Nono (a near-centenarian with a cut-off leg), Hilaire ("Mademoiselle Pansy"), a sometime cross-dressing teacher who hanged himself after a snitch falsely denounced him as a pedophile, an honest construction worker, and others. Issues of class, race, and colonialism underlie this deceptively simple, sweet but brutal tale.

The indefatigable Maryse Condé, aided by her long-time translator (and husband) Richard Philcox, offers readers yet another in a string of recent auto- 
biographical meanderings: Of Morsels and Marvels (Calcutta: Seagull Books, 2020 , cloth US $\$ 27.5$ O [French original 2015]). At the outset, she claims that "My enduring crime of treason is the subject of this book," by which she refers to her penchant for "comparing cooking with literature ... mixing sheep with goats, jute with silk." In this characteristically irreverent look at past travels (from West Africa to India, from Berkeley to New York, from Guadeloupe to Paris, and beyond), emphasizing the dishes she has been served and her varied reactions to them, she minces few words. In an almost stream-ofconsciousness style, she opines (often caustically) on places, people, and foods she has encountered during her long life, sparing few. Indeed, we felt something like relief, having been dinner guests in her Paris apartment and having hosted her to meals in both Martinique and Paris, to have been left out of her account.

Quince Duncan's Weathered Men and The Four Mirrors: Two Novels of Afro-Costa Rican Identity (Basingstoke, U.K.: Palgrave Macmillan, 2019, cloth US\$ 84.99), translated and with a helpful introduction by Dorothy E. Moseby, seem to be the first novels in Spanish (published in the early 1970s) by an author of West Indian heritage who writes about Jamaican immigrants to Central America. Born and raised in Limón, Duncan, who has published five other novels as well as short stories, sets out to contradict traditional Costa Rican nationalist identity centered on whiteness, Europeanness, et cetera. These are, as the translator argues, "novels of Afro-Costa Rican identity."

Days by Moonlight (Toronto: Coach House Books, 2019, paper US\$17.95), by prize-winning Canadian novelist André Alexis (born in Trinidad), is firmly focused on Canada rather than the Caribbean. The narrator travels through a series of small towns in Southern Ontario, including one where black people are not allowed to talk during daylight hours, and others in which he attends bizarre patriotic rituals and parades, takes a guided tour of the Museum of Canadian Sexuality, and has mind-bending conversations, but throughout displaying a love of language, poetry, and the absurd. It's a real trip, filled with fantastical, sometimes bitter, and often ironic imaginings.

In "Bookshelf 2011," we praised Bivouac (2010), by multiple-prize-winning poet and novelist Kwame Dawes, as "a dark novel about death, politics, family, and sex in a Jamaica that has a 'scarcely understood sense of temporariness and dislocation,' with dialogue that puts you right onto the streets of Kingston." Reissued now by Akashic (2019, paper US\$15.95), it reads better than ever, a dreamlike work about the island in the 198 os.

Another welcome reissue: Jamaica-born Patricia Powell's captivating, dialect-rich, debut novel, Me Dying Trial (Boston: Beacon Press, 2019, cloth US\$16.oo), first published by Heinemann in England in 1993, reissued by Bea- 
con in 2003, and now graced with an admiring introduction by Edwidge Danticat, who calls Powell "one of the most exciting writers living and writing on the island that is the Caribbean-American hyphen."

And, finally, a resurrected novel, Claude McKay's Romance in Marseille (New York: Penguin Classics, 2020, paper US\$20.00), which has languished as an unfinished manuscript in Yale's Beineke Library and, in more finished but still unpublished form, in the Schomburg Center, since some time after its initial creation in the 1920s. An introduction and "note on the text"-together, more than 50 dense pages-by editors Gary Edward Holcomb and William J. Maxwell, set the scene for this strange Lost Generation novel by the Jamaicaborn intrepid traveler and gay icon of the Harlem Renaissance. Originally intended as a follow-up to Banjo (1929), also sited in Marseille, this tale of whores, pimps, itinerant seamen, and waterfront dive bars, loosely based on a mixture of contemporary news stories about black stowaways on steamships and McKay's own seedy life in the multicultural port city, is as interesting for its insights into McKay's thoughts (for example, he fictionalizes W.E.B. Du Bois's NAACP into an organization he calls The Christian Unity of Negro Tribes a.k.a. C.U.N.T.) as for the characters or plot of the novel, though they too are often memorable. Whether viewed as one of the earliest overtly queer fictions in the Black Atlantic canon or for its views on black nationalism, the publication of this work is to be celebrated.

Now, on to short stories.

Edwidge Danticat's writing — crystalline, spare, every-word-mattering, and consistently heartrending - puts her short stories in a different league from all others. Her latest collection, Everything Inside (New York: Knopf, 2019, cloth US\$25.95), consists of eight stories previously published in such venues as Callaloo, Ms., and The New Yorker. Most of them concern Haitians who live in the Diaspora but the family relationships she describes so poignantly speak universally. Truly memorable.

Grand Union (New York: Penguin Press, 2019, cloth, US\$27.00), by awardwinning novelist and NYU professor Zadie Smith, is her first book of short stories. Raunchy or tender, gritty or ethereal, foreboding or comical, each one is told with a stunning gift for getting into the skin of diverse characters in varied situations. You'll surely like some better than others, but by the time you get to the final story - a conversation between the narrator and her dead mother who has become Nanny of the Maroons-you're likely to be sorry that this wonderful collection has come to its end.

Where There are Monsters (Leeds, U.K.: Peepal Tree Press, 2019, paper £ 9.99) is Trinidadian Breanne Mc Ivor's first collection of short stories (several of which have been previously published and won prizes). Crisp tales with mem- 
orable characters - men as well as women - who hold varying positions in the race/class structure, set in contemporary Trinidad, but with periodic irruptions of folkloric beliefs from other eras. A brisk and enjoyable read.

Hazel D. Campbell's Jamaica on My Mind: New and Collected Stories (Leeds, U.K.: Peepal Tree Press, 2019, paper £14.99), comprised of several dozen previously published short stories plus eight new ones, takes readers into a different Caribbean from that of Mc Ivor or Plastered in Pretty: a world of the 1960s, 7os, and 8os, where many people speak Creole and where the pace of life and the concerns and values are those of the grandparents of the younger writers. Even in the new stories, where cell phones and dancehall appear, it's the human relations of an earlier Jamaica, and the ever-presence of churches, that provide constancy and - through explorations of well-drawn characters-bring considerable pleasure to the reader.

Now / After: Stories (Leeds, U.K.: Peepal Tree Press, 2019, paper £9.99), by Anton Nimblett, a Trinidadian living and writing in Brooklyn, is a different kettle of short-story fish. Wildly varied in subject, location, and tone, it moves from a Haiku-like visit to Dia and its Serra rust-tinged steels to gay re-imaginings of fragments from Moby Dick, Gulliver's Travels, In the Castle of my Skin, and A House for Mr. Biswas, to a drag-queen drama set in Jersey City, and a wake in the Haitian countryside or conversations in rural Trinidad. Often intriguing, always interesting, we recommend it.

Love War Stories, by Ivelisse Rodriguez (New York: The Feminist Press at CUNY, 2018, paper US\$16.95), presents a searing and frighteningly persuasive look into the world of Puerto Rican teenage girls, mostly in New York (but also on the island and in Holyoke, Massachusetts), questing after true love despite their mothers' or aunts' marital betrayals and deceptions. The teenage and college boys who are the object of their longings appear to confirm the pan-Caribbean saying, "men are dogs." The protagonists vary from a fifteen-year-old small-town island girl; a pack of high-schoolers in Holyoke; a rejected college girl who becomes a stalker; and even some gay boys-all believable and sympathetic. The stories are tough, smart, and eminently readable.

Next, this year's crop of poetry.

Kei Miller's In Nearby Bushes (London: Carcanet, 2019, paper US\$14.99), a magnificent collection meant to be read cover-to-cover at one sitting, displays a lilting love of language, a love of Jamaican words and places and smells alongside everyday violence and singular events, like the escape during a 1988 hurricane of a troop of traveling reindeer into the hills of Portland, where they seem destined to multiply forever, despite hunters, in nearby bushes. 
Crossfire, A Litany for Survival: Poems 1998-2019 (Chicago: Haymarket, 2019, paper US\$19.95), by Staceyann Chin-New York-based performance artist, actor, and activist, and author of a 2010 memoir of growing up (and coming out) in Jamaica (The Other Side of Paradise) - begins with a preface briefly recounting experiences with her teachers (Derek Walcott, Mervyn Morris, Edward Baugh), and then moves on to a collection of poems that cry out to be read aloud. Poems about love, gender, desire, and many kinds of sex, but also family, motherhood, Jamerica, rape, racism, U.S. and international politics, and being a black and Asian lesbian poet. She's a storyteller and these poems are direct and topical, overflowing with life.

The Perseverance (London: Penned in the Margins, 2018, paper £9.99) is Raymond Antrobus's first collection since To Sweeten Bitter (2017), which we very much liked. Unlike the earlier collection, these new poems by the British Jamaican writer focus on his congenital deafness and its effects on his ways of being in the world. Reading Antrobus opens eyes as well as ears to lyrical and moving words, sounds, and experiences. The book has won two major poetry prizes and we recommend it highly.

Translations from Memory (Manchester, U.K.: Carcanet, 2018, paper £12.99) is Guyanese-British Fred D'Aguiar's eighth published collection, some 88 magnificent poems that rewrite and comment on world history, philosophy, and literature with a mixture of irony, humor, and passion. The inspirations range from Gilgamesh, Homer, and a slew of ancient Greeks and Romans through St. Thomas Aquinas, the Franciscans and Machiavelli, and on into Rousseau, the Enlightenment, and the Romantics, through twentieth-century French theorists (Fanon, Barthes, and Lévi-Strauss) and on to W.E.B. DuBois, Malcolm, M.L.K., Bearden, Wilson Harris, Aimé Césaire, Martin Carter, Walter Rodney, Walcott, Brathwaite, and "Our King James" (C.L.R.). These irreverent pieces highlight the lasting legacies of colonialism and racism while asking broadly humanistic questions about redemption and hope. The combination of lightness and deep feeling is magical.

Nothing we read this year stretches the mind quite like Vahni Capildeo's poems in Skin Can Hold (London: Carcanet, 2019, paper US\$14.99), her eighth published collection, which ranges from encounters with Shakespeare and a homage to fellow poet Zaffar Kunial to various carnivalesque Trinidadian allusions before settling on a description and analysis of her staging of an experimental theater version of Martin Carter's "I am no Soldier." This last evoked to us a precious moment in the 199os, watching twilight fall with George Lamming on the porch of our house in Martinique, looking out at the sea, while he reminisced about traipsing from one Georgetown rumshop to the next with Martin, as they talked about Walter Rodney and what might have been. 
In Enemy Luck (Leeds, U.K.: Peepal Tree Press, 2019, paper £10.99), Trinidadian literary editor and impresario Nicholas Laughlin's second collection of poetry, we are treated to a remarkably varied set of forms and puzzles and entertainments, always forcing thought, asking readers to search memories of a lifetime of reading. Found fragments, evocations of scenery, and people from around the world combine to create compelling mysteries and tales. This is a book that rewards.

Honeyfish (Kalamazoo MI: New Issues Poetry and Prose, 2019, paper US\$16.0o), winner of the 2018 Green Rose Prize, presents Trinidad-born-andraised Lauren K. Alleyne's second collection of poems-elegiac and beautiful, some evoking her own island and one in Greece, yet most expressing relentless horror at the unending U.S. White-on-Black murders and oppression: Trayvon, Sandra Bland, Tamir Rice, Charleston, Charlottesville, and burning crosses in Iowa, as well as neo-Nazis marching in Leipzig. Extraordinarily moving poetic testimony.

Poet and performer Roger Robinson, who lives between Brixton and Trinidad, displays his full storytelling skills in his latest collection, A Portable Paradise (Leeds, U.K.: Peepal Tree Press, 2019, US\$12.48), winner of the prestigious T.S. Eliot Poetry Prize. From its first moving section on the Grenfell Tower disaster to poems of slavery and modern police brutality to ironic takes on race in Britain, these poems pull you in, some making you laugh, others almost weep. Direct and important.

In I'll tradeyou this island by Cindy Jiménez-Vera (San Juan: Aguadulce, 2018, n.p.), translator Guillermo Rebollo-Gil presents his English versions on pages facing the Spanish originals. Ironic, dark, raw, filled with the small material things of life, and agnostic about the future, these poems evoke a particular vision of Puerto Rico: "There's no bread in my house / but the bananas are ripe /and we have black coffee, / no sugar." Or, "'ll trade you this island / for a matchbox / and four candles / to light / out on the corners."

I Offer My Heart as a Target / Ofrezco mi corazón como una Diana, by Puerto Rico-born Johanny Vázquez Paz (Brooklyn NY: Akashic, paper US\$15.95), is a prize-winning dual-language collection, with English translations by Lawrence Schimel. Many of the poems speak of violence, misogyny, and assaults on dignity, others of the bitterness of migration and exile, but difficulties are met throughout with a steely-eyed perseverance.

Lasana M. Sekou's latest book of poetry, Hurricane Protocol (Philipsburg, St. Maarten: House of Nehesi, 2019, paper US\$15.00), chronicles in his inimitable style the devastating passage of Irma and Maria through his beloved island in 2017. Many pages are illustrated with hieroglyphs from the Dresden Codex, depicting Mayan (standing for indigenous American) astronomical predictions and calculations. 
Sara Florian's Caribbean Counterpoint: The Aesthetics of Salt in Lasana Sekou (Philipsburg, St. Maarten: House of Nehesi, 2019, paper US\$20.00) discusses various themes (salt, sugar, maroons, and more) in the work of the poet, activist, and publisher (House of Nehesi), who has labored tirelessly for several decades for the independence and sovereignty of St. Maarten/St. Martin as a unified island. Salt, the island's major colonial export (in contrast to the rest of the Caribbean's sugar) is a central metaphor in his work; Florian's brief book is an attempt to situate Sekou's work in its broader Caribbean context.

Nomad (Philipsburg, St. Maarten: House of Nehesi, 2019, paper US\$20.00) is veteran writer, actress, and teacher Yvonne Weekes's first collection of poetry. Accessible, matter-of-fact, often surprising, these autobiographical poems recount her uncomfortable upbringing in England, her joyful return to her parent's birthplace, Monserrat (where she founded a theater company and served as the island's first Director of Culture) and her exile, after the devastating Soufrière volcano eruption in 1996, to Barbados, where she has since lived and worked, now with grandchildren.

Kendel Hippolyte's Wordplanting (Leeds, U.K.: Peepal Tree Press, 2019, paper $£$ 9.99) bring us poems about what might have been, the world that was once hoped for and dreamed of and fought for but never came to pass: "i woke one morning and the Caribbean was gone." He seeks her, first by the sea, then in the town, then in the market, then at a crossroads, and finds only occasional glimpses of her presence "in a far hillside district ... or a glint of zinc from a house changing half of its roof on a Saturday half-day, given to a koudmen, lendhand, gayap, koumbit, fajina, jollification, maroon, gotong rojong ... Harder to find now." So, a sense of loss in a modernizing, globalizing St. Lucia, but also small pleasures in familiar domestic acts - morning coffee, making a bed with a loved one. In his seventh published collection of poems, Hippolyte's languorous rhythms draw us in: mature, thoughtful work that rewards.

St. Lucian poet, journalist, and librarian John Robert Lee has done the Caribbean literary world a great service by conceptualizing and editing Saint Lucian Writers and Writing: An Author Index of Published Works of Poetry, Prose, and Drama (London and Trafalgar, Dominica: Papillote Press, 2019, paper $£$ 9.99). The book, which includes not only writers of S.L. origin but also those who have written about the island, is divided by genres: poetry, short fiction, novels, drama, literary periodicals, and so forth, and it includes unpublished dissertations and theses about the island as well. A labor of love, filled with surprises, that can be enjoyed by many.

A Lesson on Wings (Vieux Fort, St. Lucia: Jako Books, 2019, paper US\$21.95), by senior St. Lucian poet Modeste Downes, is best when-in a nostalgic mode- - he recounts the storied past of his beloved Vieux Fort and rues its 
present, with international travelers touching down at Hewanorra and leaving in taxis and rental cars to the land of all-inclusives and disappearing mangroves.

A richly informative 16-page foreword by translator (and University of Chicago professor) Haun Saussy introduces When the Pipirite Sings: Selected Poems (Evanston IL: Northwestern University Press, 2019, paper US $\$ 18.95$ ), by the late Haitian writer and neurologist Jean Métellus. Written in Parisian exile from the Duvaliers, in French, these poems are nevertheless Haitian to the core, indelibly evoking the Jacmel of the writer's youth. Sometimes Homeric, sometimes Césairian in tone and reference, they engage with the lwas, the land, the sun, and the sea, with the Middle Passage and the great figures of Haitian history always lurking in the background.

We welcome the paperback reprint of The Collected Poems of Édouard Glissant, translated by Jeff Humphries \& Melissa Manolas and edited (with an introduction) by Jeff Humphries (Minneapolis: University of Minnesota Press, 2019, paper US\$22.95), which originally appeared in cloth from that publisher in 2005. The introduction could have been updated to reflect changes in postcolonial scholarship during the past decade and a half, but the singular poems now permit Glissant to speak from the grave, as his literary influence continues to increase.

We also welcome the first English-language translation, by Nathanaël, of Glissant's earliest published work, Soleil de la conscience (1956) as Sun of Consciousness (New York: Nightboat Books, 2020, paper US\$14.95), which recounts in poetic prose (and occasional straight poetry) his complex feelings upon arriving to study in 1946 Paris, where he remained for eight years. His thoughts range widely, from racism and colonialism to universalism and poetry: it is "a time of chaotic opening ... prose, chaos, measure, knowledge and poetry being signs of my experience, seen from inside. Outside, it is the French truth opposing mine." Or again, "And here I am freezing between these two oceans; the true and immortal abyss of the sea, on the one hand, that exiles me from myself (from my reality, from my roots in the ground planted like so many pitchforks of truth); then the other, the enormous Wave besides that rolls here, Parisian ... I know of a sudden its secret: and it is that Paris is an island, that intercepts from all sides and diffracts forthwith." Twenty-five years before the publication of Le discours antillais, this early work contains only hints of that Antillean manifesto but leads more directly into L'intention poétique and perhaps even toward the idea of le Tout-Monde.

And, finally, works of nonfiction not otherwise reviewed in the NWIG:

Recently retired Yale professor Hazel V. Carby has gifted us a remarkable book, Imperial Intimacies (London: Verso, 2019, cloth US\$29.95), part memoir, 
part historical study, and deeply personal throughout. Exploring family history, beginning with her birth in England of a Jamaica-born, World War II RAF pilot and a Welsh mother, she traces better than any book we can remember the ways that "Black British" is truly an oxymoron, as well as the broader consequences of race and empire. Following oral, and eventually archival, genealogy, she carries us to eighteenth-century Jamaica and Bristol and slowly brings us up to the present, all the way examining how the terrible violence of colonialism and empire has shaped, and continues to shape, ordinary people's lives.

In Voices of the Windrush Generation: The Real Story Told by the People Themselves (London: Blink, 2019, cloth £18.99), journalist David Matthews (who, born in Hackney of British Guiana immigrant parents, styles himself a member of the Windrush 2.o generation) interviews two handfuls of Windrush-era West Indians living in the United Kingdom, reminiscing about their (British) West Indian childhoods, their frightening and discrimination-filled first years in the mother country (and continuing race prejudice till today), and their adult lives as nurses, seamstresses, teachers, musicians, and parents. Clumsier than the oral history collections by his model Studs Terkel, this one nonetheless lets people whose whole lives have been under the thumb of empire speak out, each in their own voice. It makes the Windrush scandal of recent years, which is barely touched on in the book, all the more heartbreaking.

Journalist Ross Kenneth Urken, a self-described Jewish boy from New Jersey who speaks with a Jamaican accent, offers a memoir, Another Mother (Kingston: Ian Randle Press, 2019, cloth US\$18.oo), devoted to his Jamaican nanny Dezna Sanderson, who not only raised him but also served as peacemaker in his parents' dysfunctional marriage. Moving back and forth between tales of his childhood and his young adult quest to learn about Dezna's pre-USA life in Jamaica, through trips and interviews with her scattered family members, this somewhat self-indulgent book captures the realities of thousands of late-twentieth-century Caribbean women immigrants and serves as a loving homage to their sacrifices.

If you wish to know the remarkable woman that is Christiane Taubira, her most recent memoir, Nuit d'épine (Paris: Plon, 2019, paper €16.90), is an excellent start. Vignettes of her life, from details of growing up in Guyane all the way to dealing, as France's minister of justice, with the bombing of the Bataclan, are spiced with lyrics from the songs she loves (Brazilian, Cuban, West African, French, and American) and excerpts from her favorite poets (who range from Césaire, Damas, and Monchouachi to Countee Cullen, Pablo Neruda, and Ossip Mandelstam). She invites us to read over her shoulder as she discovers the work of Maryse Condé, Steve Biko, and others, and as she lays bare her life expe- 
rience, she constantly enriches her reminiscences with references to authors and works in a variety of world literatures (and cinemas). In short, she opens a window, if only partially, into how she became one of the most interesting and, for many, admirable public figures of our time.

Aftershocks of Disaster: Puerto Rico Before and After the Storm (Chicago: Haymarket Books, September 2019, paper US $\$ 17.00)$, edited by Yarimar Bonilla \& Marisol LeBrón, is a truly important anthology—essays, poems, and photos that grapple with the island's long-standing colonial problems and post-Maria dilemmas. As Arcadio Díaz-Quiñones writes in his foreword, "the threat of total collapse continues to raise major themes of discussion in a global context: colonial capitalism, human rights, gender equality, democracy, unpayable debt, climate change, migration and citizenship, environmental policies, education, and health care." More than thirty interventions by specialists of all stripes are deftly woven together by the editors to bring readers a vivid picture of the current imbroglio as well as useful pointers toward building a sustainable future for the island's people.

A Girl Named Lovely, by Catherine Porter (New York: Simon \& Schuster, 2019, paper US\$17.99), is a Canadian journalist's story of how she first discovered Port-au-Prince while reporting only days after the 2010 earthquake and became involved in financially supporting a two-year-old girl miraculously pulled from the rubble and later much of her poverty-stricken family as well as a whole school. It recounts the ethical conundrums and private joys and frustrations she experienced as she witnessed and participated in the international aid effort in the years following the disaster. Well-meaning, honest, somewhat selfindulgent, and sometimes slightly breathless in tone, it stands as one woman's personal reaction to the complex realities of inequality faced by almost any outsider in Haiti.

Agua por todas partes (Barcelona: Tusquets, 2019, paper $€ 19.00$ ) is a collection of Leonardo Padura's essays/reflections on becoming and being Cuba's best-known writer internationally. The book's first part concerns his feelings of rootedness in the barrio of Mantilla, on Havana's southern edge, and why he could never leave. But there is also much about contemporary Cuba, his irritation at the widespread love of reggaetón, descriptions of the daily lucha of his friends and neighbors, his thoughts about exile, and dialogues with the work of other writers, particularly Alejo Carpentier. The rest of the essays are loosely autobiographical but necessarily speak about evolving Cuban realities since the 1970s. The final chapters are more explicitly literary, engaging the form of the novel and the act of writing, with Cuban preoccupations, from baseball to the persecution of homosexuals, always in the background. In addition to Carpentier, Padura highlights the work of José Lezama Lima and Vir- 
gilio Piñera (who wrote, in 1943, of "la maldita circonstancia del agua por todas partes") and displays a wide range of reading-novelists, poets, and literary critics.

Goodbye, My Havana: The Life and Times of a Gringa in Revolutionary Cuba (Stanford CA: Redwood Press, 2019, paper US\$24.00) is an autobiographical account by Anna Veltfort, presented in "graphic memoir" form, of her early life in Berkeley, California, her left-leaning family's 1962 move to Cuba when she was of high-school age, her sexual (gay) awakenings, her life at the University of Havana (filled with revolutionary ardor as well as persecution), and her final departure for the United States in 1972. The graphic panels depict a number of her experiences during her Cuban decade, from meeting Fidel and Che and working in sugar harvests and peasant education drives to watching purges and show trials. The tone is frank and cheery, the story zips right along, as both the author and the Revolution come of age.

In North of Havana: The Untold Story of Dirty Politics, Secret Diplomacy, and the Trial of the Cuban Five (New York: The New Press, 2019, cloth US\$26.99), veteran trial lawyer Martin Garbus, who earlier represented prominent dissidents including Daniel Ellsberg, Cesar Chavez, and Cuban poet Heberto Padilla, tells the gripping story of his role in this Kafkaesque case of international intrigue. The highly charged political world of 1990 Miami's Little Havana comes alive, as we see the role of elite Cuban exiles in influencing everything from the appointment of U.S. attorneys to national elections. From the original show trial of the five Cubans (who were, indeed, Fidel's spies, though innocent of the trumped-up murder charges that they were convicted for), conducted in the immediate wake of the Elián González affair, all the way through the ObamaRaúl-negotiated prisoner exchange that concluded the matter a decade and a half later, the author lays bare the working of the U.S. court and prison system, emphasizing its dangerous political vulnerabilities. Garbus wrote the book, he says, "to show how our government can subvert the press and interfere with our jury system. It chronicles an unprecedented pollution of the American legal system in order to advance a political cause." Though chronicling the recent past, its relevance for the present and immediate future is acute.

A to $Z$ of Caribbean Art, edited by Melanie Archer \& Mariel Brown (Port of Spain: Robert \& Christopher Publishers, 2019, paper US\$ 44.05), offers singlepage introductions to almost 300 twentieth- and twenty-first-century artists with ties to the Caribbean by birth, parentage, residence, adoptive home, or other links, many of whom maintain relationships both in and out of the region. Flipping through its pages, which include a color image of work by each artist, one cannot but be struck by the richness of media-painting, sculpture, 
photography, engraving, video, collage, and glass to works made from fishing line and mosquito netting or a cement mixer and sunscreen. (Not surprisingly, there were difficult choices; for example, Martiniquan photographer Robert Charlotte is included, but well-known Martiniquan photographer Jean-Luc de Laguarigue is not.) All in all, a valuable resource for anyone interested in art of the Caribbean.

Committed to Memory:The Art of the Slave Ship Icon, by Cheryl Finley (Princeton NJ: Princeton University Press, 2018, cloth US\$49.50), began as a 2002 Yale University dissertation but now benefits from considerable further research and travel. Generously illustrated in color, the book explores the initial (1788) impact and continuing afterlife of the iconic woodcut of the lower deck of the Liverpudlian slaver Brookes. A remarkable range of artists and artworks are engaged, from the eighteenth century to the present, tracing the icon's role in multiple movements of political protest and even in modern-day roots tourism. Having coauthored a book (with Sidney W. Mintz) that used the icon on its jacket, I (RP) learned here of uses I'd never have imagined—it is indeed the central image in what Finley calls the "mnemonic aesthetics" of transatlantic slavery, a foundational, if terrifying and persisting, symbol of the Black Atlantic.

Antonio Martorell is the gift that keeps on giving ... most recently a collection of memories and reflections that offer yet more of the visual creativity, poetic sensitivity, and human warmth we've come to know from his earlier work. Pierdencuentra (San Juan: Gaviota, 2019, paper n.p.), another tactually and visually beautiful object, offers touching word-portraits of his family (grandfather don Antonio who lost his lefthand pinkie, auntie Lucy who cooked up a fantastic goulash, aunt Consuelo who lost her name, one letter at a time ...) with side trips to other things on his mind ("how words and illustrations found themselves on one of my pages," etc.). He has said it is about things lost and found, without always being able to know which is which. The volume is accompanied by a $C D$ of el maestro reading some of his word portraits.

Another very beautiful (though in a more conventional sense) book focusing on an artist living and working in Santurce, Puerto Rico, is an exhibition catalog on the work of Zilia Sánchez organized by the Phillips Collection in Washington DC. Zilia Sánchez Soy Isla (New Haven CT: Yale University Press, 2018, cloth US $\$ 50.00$ ) recounts Sánchez's life from her early years in Cuba to travels in Europe and a decade in New York before a return to the Caribbean in 1971. Essays reflecting on her work, which "resists traditional categorization and floats in between" like an island, are accompanied by hundreds of fullcolor images, from sensuous erotic topologies, shaped canvasses, and "tattooed works" to the acrylics on stretched canvas that dominated the exhibition. 
L'Art à Cuba, by Gilbert Brownstone, with photographs by Camilo Guevara (Paris: Flammarion, 2019, cloth $€ 39.90$ ), is both elegantly produced and fascinating to read. An opening essay by Graziella Pogolotti recounts the history of the national art school, which began in an abandoned golf course; Guevarason of "le Che"-reflects on his father's interest in photography; and Brownstone offers a substantive introduction to the place of art in Cuban culture. But it's the 32 artists' statements (from interviews by Brownstone), each several pages long and beautifully illustrated by Guevara, that constitute the heart of the volume. (That said, we have to assume that if the artists had been French rather than Cuban, Flammarion would have taken a bit more care in the halfpage promotional text that comes with the book, which misspells Wifredo Lam, Gilbert Brownstone, and Camilo Guevara [twice].)

Picturing Cuba: Art, Culture, and Identity on the Island and in the Diaspora, edited by Jorge Duany (Gainesville: University Press of Florida, 2019, cloth US $\$ 80.00$ ), is based on a 2017 conference held at the Frost Art Museum, part of Florida International University where Duany teaches and directs the Cuban Research Institute. Fifteen contributors-academics and art collectors, all apparently living in the United States-highlight relations between Cuban and Cuban-American art (painting, photography, architecture) and cultural identity from the seventeenth century to the present. The bulk of the book is devoted to the twentieth and twenty-first centuries, and Miami-based artists and institutions often take pride of place. The 48 color plates and over a dozen black and white images remind us of the vibrancy of Cuba's artistic output and helpfully illustrate the essays, which cover topics from colonial prints, national identity, and the role of women artists, through Concretism, to art in the Diaspora.

Hew Locke: Here's the Thing is the visually stunning catalog for an exhibition of works in various media by Guyanese/British artist Hew Locke, who styles himself part of the "post-Windrush generation." Essays by historian Richard Drayton and curator Diana Tuite comment usefully on the way Locke has played with sources from ships and houses to colonial statues and share certificates to produce a rich and imaginative evocation of the Caribbean past and present, with a special focus on voyages. The catalog (paper n.p.) is a 2019 copublication of the Ikon Gallery in Birmingham, the Kemper Museum in Kansas City, and the Colby College Museum of Art in Waterville Maine, where the exhibition was shown.

In Born Ya: The Life and Loves of a Jamaican Painter (London: Beattie Books, 2019, paper US\$15.99), Judy Ann MacMillan offers a forthright account of growing up as a light-skinned girl in a privileged family in Kingston, her art school years in Scotland, her return home and short-lived marriage to an American 
engineer who took her to Ohio, and her settling back into the Jamaica of the Manleys where, despite gender stereotypes, she finally finds herself as a painter. The book brims with salient observations about her countrymen, both rural and urban, and her love of, and curiosity about, the island.

An American Odyssey: The Life and Work of Romare Bearden, by Mary Schmidt Campbell (New York: Oxford University Press, 2018, cloth US\$34.95), almost completely ignores the Caribbean work of the master collagist and painter, with hardly a word about his hundreds of Caribbean watercolors - the thirty or so Martinique paintings, the several hundred referring to St. Martin, the Carnival series, or the astounding Rituals of the Obeah. For anyone interested in his life in the Caribbean and its influence on his art, our own Romare Bearden: The Caribbean Dimension (or its French translation) remains the touchstone.

With an over-the-top foreword by Ishmael Reed, Cimarrón: Freedom and Masquerade (London: Thames \& Hudson, 2019, cloth US\$40.00) consists of art photographer Charles Freger's glossy, vividly colorful, dramatically costumed, carefully posed carnavelesque images from around the African diaspora: Guadeloupe, Martinique, Guyane, Antigua, Monserrat, Saint Croix, Haiti, the Dominican Republic, Cuba, Brazil, Colombia, Mexico, Belize, Panama, Peru, and New Orleans. The two dozen pages of explanation at the book's end, describing the carnival groups and the characters depicted, are less inaccurate than one might expect from this sort of project.

The Haiti Reader: History, Culture, Politics, edited by Laurent Dubois, Kaiama L. Glover, Nadève Ménard, Millery Polyné \& Chantalle F. Verna (Durham NC: Duke University Press, 2020, paper US\$29.95), presents well over 100 texts in more than 500 lovingly assembled pages - everything from fiction, poetry, songs, and folktales to scholarly essays and political tracts, beginning with the Tainos, slavery, and the Revolution, moving on through the U.S. occupation, the Duvalier years and their aftermath, and continuing right up to the present. Much of the volume, which is intended to highlight Haitian points of view, offers small tastes of longer works, whetting the reader's appetite for more. The English translations from French and Creole are fluid and welcome. The collection introduces many of Haiti's major writers and thinkers and will be a boon to college teachers, a solid basis for a course on the first independent nation of the Caribbean.

The Cuba Reader: History, Culture, Politics, edited by Aviva Chomsky, Barry Carr, Alfredo Prieto \& Pamela Maria Smorkaloff (Durham NC: Duke University Press, 2019, paper US\$32.95), is an expanded second edition of the 2003 work we praised in Bookshelf 2004. With more than twenty new selections exploring the post-Fidel years, this thick volume continues to be an excellent introduction to the island and its people. 
United States Reconstruction across the Americas, edited by William A. Link (Gainesville: University Press of Florida, 2019, cloth US\$34.95), consists of three chapters, the first concerning the United States and Brazil, the second the United States and Mexico, and the third, by Edward B. Rugemer, the effects of news about Jamaica's Morant Bay Rebellion of 1865 on Radical Republican journalists and legislators in the United States, as they dealt with white supremacist efforts to undermine the recently enacted Emancipation.

Beryl McBurnie (Kingston: University of the West Indies Press, 2018, cloth US\$25.00) is Trinidadian journalist Judy Raymond's brief, dutiful, but affectionate portrait of the anticolonialist dancer who championed her country's Afro traditions (as well as those of the rest of the Caribbean, from the "talking drums" of Suriname to Martinique's "belé" and beyond) and founded the Little Carib Theatre in Port of Spain (which also housed Derek Walcott's Theatre Workshop), and whose work and influence spanned the whole second half of the twentieth century.

In Sons of the Soil: The Maingots and French Creoles in Trinidad History (CreateSpace, 2019, paper US\$19.95), prolific Caribbeanist Anthony P. Maingot delves deep into his family's history, beginning with the 1776 voyage of an ancestor from Bordeaux to Martinique and, ten years later, to Spanish Trinidad. The English conquest and the growth of slave plantations led, in the early nineteenth century, to "a French culture tinged with West African influences ... [and a] French Creole identity known for its congenial life style, its music, cuisine and piquant sense of humor. So was Carnival and Calypso born." Conceived as a gift to his family, the book contains a wealth of local history (understandably, a bit French Creole-centric).

Afro-Catholic Festivals in the Americas: Performance, Representation, and the Making of Black Atlantic Tradition (University Park: Pennsylvania State University Press, 2019, cloth US\$89.95), edited by art historian Cécile Fromont, consists of eight chapters that range from New Orleans to Brazil (with half on the latter) and only one on the Caribbean. Dianne M. Stewart's dense chapter, "The Orisa House that Afro-Catholics built: African Antecedents to Yoruba Religious Formation in Trinidad," will be of interest to all scholars of Caribbean religion, as it criticizes the assumptions and methods of both historians and anthropologists and raises questions that stretch well beyond Trinidad or Shango.

My Father Is No Longer There (Vieux Fort, St-Lucia: Jako Books, 2019, paper US\$24.95) is a memoir by St. Lucian Anderson Reynolds centered on the recent death of his father, a respected Adventist elder and beekeeper. About Reynolds's 2017 novel, The Stall Keeper, we wrote that "the strong very local color somewhat makes up for the prosaic writing." This time, there's less local color and more inner torment. Unfortunately, the writing remains rather flat. 
Zwazo, récit de vie d'un prêtre hindou commandeur d'habitation à la Martinique, by Gerry L'Étang \& Victorien Permal (Paris: HC Éditions, 2018, paper $€ 12.50$ ), is a wonderful little book that begins with a lyrical homage by anthropologist Jean Benoist, who first met Zwazo in 1957 and, with his help, made a documentary film about Hindu religious practice in Martinique. Becoming the go-to interlocutor on all things Indian, and the last real Tamil-speaker of the island (nineteenth-century, immigrant version), Antoine Tangamen a.k.a. Zwazo (1902-92) even made a cameo appearance in Naipaul's The Middle Passage. Martiniquan anthropologist Gerry L'Étang met him in 1980, while doing doctoral research on the Hindu population of Martinique and, between 1986 and 1990, conducted the interviews (along with Guadeloupean Victorien Permal) that make up the bulk of this work. The book is presented as a firstperson, chronological life history, beginning with the departure of the narrator's grandmother from India. (After the abolition of slavery, some 25,000 Indians - 9o percent Tamils, with only 15 percent Muslims - were transported to Martinique as indentured laborers, the majority through the French port of Pondichéry, with most ending up in the north of the island.) Zwazo paints a picture of plantation life during the whole course of the twentieth century - canecutting (he eventually became a commandeur ["overseer" or "foreman"] in the fields), labor strikes and trials, and his life as a Hindu priest who sang and spoke with the ancient (now creolized) gods. Extensive historical and ethnographic notes enhance the text, which is followed by annexes that add comparative materials as well as relevant historical texts.

Madeleine Jouye de Grandmaison has chronicled her life as a Martiniquan activist in Une Voix pour le Nord: Le Nord mon terroir, La Martinique mon pays (Saint-Denis La Plaine, France: Seed Publications, 2018, paper € 27.00). Back in 1987 , as we were preparing to move to Martinique from Paris, Michel Leiris told us that the one person we should be sure to meet was Madeleine, then a crucial player in Aimé Césaire's political world. For anyone curious about what it takes to promote a region - culturally, politically, touristically—, this is a rich archive (225 oversized pages plus a UsB key), brimming with evidence of the many dimensions that promotional activism demands, from letters, maps, petitions, protests, speeches, and quiet diplomacy to archival research and, above all, a caring, passionate commitment. Serving in political positions as diverse as long-time vice-president of the Conseil Régional, president of the Comité Martiniquais du Tourisme, and Députée Européenne, she has worked tirelessly for her beloved island.

In La forge de Zobel: Textes et reportages parus dans Le Sportif de Fort-deFrance de 1938 à 1959 (Paris: Scitep, 2019, paper € 22.0o), literary critic Charles W. Scheel has gathered together some 200 pages of little-known writings first 
published in a sports-oriented Martiniquan newspaper that had the courage to print these often-fascinating literary works by this friend and student of Césaire, better known for such novels as La Rue Cases-Nègres and Diab'là. Prefaced with an interesting personal reflection by Zobel's daughter Jenny, these stories, journalistic reports, and memoirs add measurably to the Zobel archive, as well as to an understanding of the continuing meaning of Martinique to members of Zobel's generation who, like him, moved on to the metropole.

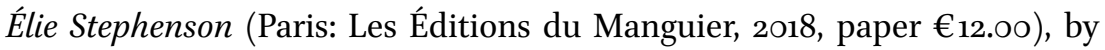
Lydie Ho-Fong-Choy Choucoutou \& Monique Dorcy, is an oversized, 56-page publication in the Collection Orénoque, which is intended to introduce French Guianese authors. This one follows others devoted to Léon-Gontran Damas and Alfred Parépou, effectively situating Stephenson-poet, playwright, novelist, and media commentator-within the literary and political history of postWorld War II Guyane, and includes several pages of interviews with the author, as well as numerous period illustrations.

The Island of Lace:Drawn Threadwork on Saba in the Dutch Caribbean, by Eric A. Eliason with photographs by Scott Squire (Jackson: University of Mississippi Press, 2019, cloth, US $\$ 40.00$ ), is a beautiful, extended homage to the women responsible for making Saba known as "The Island of Lace." First clarifying the essential difference between lace made elsewhere (built up from threads) and on Saba (made by removing threads from cloth), it offers a rich history of the art (including its commercial aspects since its beginnings in the early twentieth century), illustrates hundreds of named patterns, and ends with essays on individual "Saba Lace Ladies" working today.

In Schoolboy: Memories of My Early Years in Wartime (Philipsburg, St. Maarten: House of Nehesi, 2018, paper, US\$15.00), Gerard van Veen-a former priest who came to the Caribbean in 1961, living in Aruba and St. Maarten, where he wrote newspaper articles and served as probation officer and university lecturer-recounts his Dutch childhood, living in German-occupied Alkmaar.

Encountering - Retracing-Mapping: The Ethnographic Legacy of Heinrich Harrer and Peter Aufschnaiter, edited by Mareile Flitsch, Maike Powroznik \& Martina Wernsdörfer (Zurich, Switzerland: Ethnographic Museum, University of Zurich/Stuttgart, Germany: Arnoldsche Art Publishers, 2018, US \$70.oo), includes a 3o-page chapter by curator Maike Powroznik (with a contribution by Saamaka-born Vinije Haabo) about Harrer's recently rediscovered collection of hundreds of Saamaka woodcarvings, vacuumed up during an 11-day stay in 1966. Famed in Germany and Austria as a mountain climber and explorer (particularly in Tibet), Harrer, who once received a medal from Hitler, somehow 
managed to acquire these objects—food stirrers, paddles, peanut-grinding boards, combs, and drums - during his very brief stay, accompanied by cameraman Herbert Raditschnig (who was filming for German television), Belgium King Leopold III, and various Dutch colonial officials. The chapter discusses the 1966 visit, includes excellent color photos of many of the pieces, and describes the ongoing collaboration between the Zurich museum and the fledgling Saamaka Maroon Museum in Pikiseei, on the Suriname River.

Shadows in Suriname, by Margaretta Pos (Lindisfarne, Tasmania: Forty South, 2016, paper, AUD 25.00), consists of vignettes-mostly by the author (a Tasmanian writer/journalist), but a couple by her more famous father Hugo Pos (the late Suriname-born writer and jurist) - that trace their complex family relations as well as her own brief visits to Suriname as an adult to explore her Jewish ancestry. Despite the emotional meaning to the author, her account of the country remains at travelog level.

What the Oceans Remember: Searching for Belonging and Home, by Sonja Boon (Waterloo ON: Wilfrid Laurier University Press, 2019, cloth US\$27.99), is another highly personal (often intimate) memoir but a far more interesting one. The author, formally a professional flautist but now a feminist university professor in Canada, tells us that her father's family came from Brabant but, speaking of her mother's, that "Sometime around 1935 [in Suriname], my Catholic grandmother with her Chinese name and her Hindu indentured ancestors met my grandfather, the child of a German man and his Creole concubine and the descendant of enslaved Africans, and fell in love." Her book recounts her efforts to delve deeply into her Suriname roots, which began with nineteenth-century African plantation slavery and Chinese and Indian indentured labor. Sophisticated musings about research in multiples archives, walking the streets on several continents, interviewing far-flung relatives, and engaging in constant self-questioning about identity, race, origins, and belonging make this a rewarding read, as Boon is unafraid to write about what the experiences of diverse ancestors might have been like, even while questioning her right to attempt this act of historical imagination.

After two decades in New York working as a cinematographer, Milton Kam returned to his native Suriname to photograph its indigenous peoples. The resulting book, Points of Recognition: Suriname's Indigenous Peoples in the 21st Century (Dedemsvaart, the Netherlands: Kapelka Books, 2019, paper €19.99), presents beautiful color photos with informative captions. People are identified by name, the many villages visited are briefly discussed, and contemporary issues (such as struggles with the national government for land rights and education) are made clear. Individuals are shown in their complex presentday realities, whether gardening or celebrating festivals or fishing in mercury- 
polluted rivers or studying at boarding schools in the capital far from their families. Published with the cooperation and collaboration of VIDS, the official organization of indigenous peoples in Suriname, this is a modest, but admirable work.

Calling this next book shameless plagiarism might be too kind. Sur les traces de Boni: Histoires de marronnages. Suivi de l'émergence d'un peuple, by Collectif Mama Bobi (Matoury, Guyane: Ibis Rouge, 2019, paper €28.oo), claims to present Aluku history from an Aluku perspective. The bibliography lists some twenty works but the footnotes refer to many dozen more sources (in partial form, such as "Genovese 1975") that are nowhere listed or spelled out—we noticed, for example, frequent cryptic references to Price 1976, 1982, 1983 and 1990 in the footnotes but the only "Price" reference in the bibliography is "1973" (Maroon Societies). More troubling is the very close reproduction/translation of work by Wim Hoogbergen (particularly, The Boni Maroon Wars in Suriname [orig. 1990]), which makes up the bulk of the book, generally using the old trick of citing the archival sources from Hoogbergen's writing but not the fact that they were taken from him. (And he is not the only scholar quietly plagiarized.) This hotchpotch of a text may offer some young Alukus a taste, in French, of their people's early history, but it is a shame that this must substitute for honest, scholarly work. (The collective that produced this book received considerable funds some years ago from the State to produce a French translation of Hoogbergen's book, which was never accomplished; this publication is hardly what the grantors would have expected.)

In Les Bushinengué de Guyane: Rites et croyances autour du textile (Paris: L'Harmattan, 2017, paper $€ 20.00$ ), Gabonese Landri Ekomie-Obame makes a well-meaning attempt to explain the life of Aluku Maroons, with whom he spent four years as a schoolteacher. Placing traditional clothing (especially what he calls the "nay pangi" [decorated skirt-cloth]) at the center of everything from childbirth, menstruation, marriage, funeral rites, and relations with ancestors, his analysis suffers from fanciful etymologies and confused citations, as well as a feeble grasp of the most basic elements of Maroon textile arts, such as the distinction between embroidery and patchwork or the fact that Maroon kamisas are loincloths, not shirts or capes. Jean Moomou's preface is politely on-target in suggesting that the book would have benefitted from more care with ethnographic facts and a clearer historical perspective-Ekomie-Obame proposes, largely on the basis of visual resemblances, that most of Maroon culture derives directly from that of West and Central Africa.

A Global History of Runaways: Workers, Mobility, and Capitalism, 1600-1850, edited by Marcus Rediker, Titas Chakraborty \& Matthias van Rossum (Berkeley: University of California Press, 2019, paper US\$34.95), is a curious collection 
of papers first presented at 2015/2016 conferences in Amsterdam and Pittsburgh. The aim is laudable: bringing together analyses of one form of resistance ("running away") by "workers of all kinds-slaves, indentured servants, convicts, domestic workers, soldiers, and sailors ... during global capitalism's long ascent from 1600 to 1850 ." But only three of the eleven chapters concern the Caribbean and they are strictly circumscribed (the Danish West Indies, 167287; the Leeward Archipelago, 1627-1727; and the British Caribbean, 1808-28), with the rest on Bengal, Australia, the Cape of Good Hope, and more. Completely unmentioned are Suriname Maroons, Jamaican Maroons, and the other important cases one might expect in such a collection (though the cover of the book does feature J.G. Stedman's "rebel Negro armed \& on his Guard").

We welcome a new edition of Michèle-Baj Strobel's Les gens de l'or:mémoire des orpailleurs créoles du Maroni (Guyane) (Paris: Plon, 2019, paper $€ 27.00$ ), now in the prestigious Terre Humaine collection. Peter Redfield reviewed its initial publication two decades ago in NWIG 74(3\&4); the expanded edition has just won the Prix du livre d'histoire des outre-mer 2020. This remarkable work about the final generation of Creole goldminers from St. Lucia and neighboring islands who made their lives in the hinterlands of Guyane has a new introduction, bringing the situation up to the present, as well as the original preface by Richard Price.

Once again, Rosemarijn Hoefte has provided an overview of recent (mostly-) Dutch-language books that may be of interest to our readers:

Starting with Suriname, Indianen van Suriname: Bruggenbouwers en erfgoeddragers van een vergeten volk, text by Petra Nelstein, photographs by Diederik van Goethem (Volendam, the Netherlands: LM Publishers, 2019, paper €19.50), aims at a Dutch general audience. In 21 short chapters, readers get a poorlywritten crash course on the history, culture, society, and spirituality of indigenous people in the Para district. The book is based on a recent expedition that was inspired by the discovery of the manuscript of the Penard brothers (Frederik Paul and Arthur Philip) during the renovation of the Dutch National Museum of Ethnology in Leiden in 2010 (according to the Museum's website) or 2011 (according to the book). The link to the Penard manuscript is weak at best. Enjoy the book for the photographs.

The source publication Ten exempel van anderen: De processen tegen opvarenden van de piratenschepen Trompeuse en Resolution in Suriname en op St. Thomas in 1684 (Zutphen, the Netherlands: WalburgPers, 2019, cloth $€ 27.50$ ) details the voyages of these pirate ships, the conditions on board, and the constantly changing composition of its crews, as well as the four court cases (three in Paramaribo, one on St. Thomas). In the substantial introduction, the editors Karwan Fatah-Black and Aart Ruijter argue that the Trompeuse's captain, 
Jean Hamlin, initiated a new era, as he was one of the first to raid outside the Caribbean by sailing to West Africa and North America.

De mensen van Vossenburg en Wayampibo: Twee Surinaamse plantages in de slaventijd (Hilversum, the Netherlands: Verloren, 2019, paper $€ 25$.oo), by Bert Koene, is a history of two plantations in Suriname in the eighteenth and nineteenth centuries, based on documents by Dutch owners Gerard de Vree and the Brantsen family. It is an interesting addition to the publications on the economic history of plantation Vossenburg by Humphrey Lamur, published in the 1980 os and 199os. It includes lists of the enslaved population of Vossenburg in $1705,1728,1744,1760,1784,1852$, and 1863 and of Wayampibo in 1727,176 o, and 1784.

A small gem: Tenen van de leguaan: Verhalen uit de wereld van Surinaamse leprapatiënten. Over lepra, slavernij, kolonialisme en de Surinaamse ecologie (Volendam: LM Publishers, 2019, paper € 24.50), by Henk Menke, Toine Pieters, Melinda Reyme \& Jack Menke, is a truly interdisciplinary study of leprosy. Divided into four parts, the volume discusses the history of colonialism, slavery, and the fear of leprosy, followed by ten oral histories of leprosy sufferers. The two final parts analyze stigmas, taboos, discrimination, and (religious) treatments among the different population groups as well as the current approach to the disease. This richly illustrated book offers a non-European perspective on the evil that locals called boasie; it includes short summaries in English, Portuguese, and Spanish.

Moving fully to the twentieth century. Op zoek naar Papa Koenders: Over een strijder voor emancipatie in het koloniale Suriname (Volendam: LM Publishers, 2019, cloth €19.50), by Jules Rijssen, Roy Wijks \& Andre Reeder, is slightly uneven but includes some fascinating chapters $(3,6,7)$ with reminiscences by people who were acquainted with the teacher Julius "Papa" Koenders (1886-1957). Koenders was an advocate for Afro-Surinamese culture in general and Sranan Tongo in particular. His life and activities, especially his editorship of the influential magazine Foetoe-boi, are highlighted in the volume's first half. The interviews with people who knew him give a lively sketch of AfroSurinamese sociocultural life in Paramaribo in the 1950s as well as the cultural and political nationalist movement in the 1950s and 196os. The book includes a CD with texts and songs performed by Randy Kersout-Gunning.

After 50 years away, sociologist Herman Vuijsje returned to Suriname where he did his MA research on multireligiosity. God zij met ons Suriname: Religie als vloek en zegen (Zutphen, the Netherlands: WalburgPers, 2019, paper €19.99) focuses on the pervasiveness of both religion and fear in the country. This fast-paced, journalistic account zooms in on new religious developments; the author is especially fascinated by the emancipation of Winti. 
Bruynzeelwoningen in Suriname, met herinneringen van Kees Tempelaar, by Karolien Janssens, Marte Wierenga \& Dirk Laporte (Volendam: LM Publishers, 2019, cloth $€ 24.50)$, details the history of the iconic, modern Bruynzeel homes made from Suriname timber between 1955 and 199o. These precut prefab houses were also exported, for example to Grenada after Hurricane Janet in 1955. This richly illustrated volume includes the extensive memories of a former Dutch employee, Kees Tempelaar, and thus doubles as a company history of Bruynzeel in the postwar era. For specialists.

In Suriname there seems to be a mini-boom in autobiographical and family histories. K.R. Sing's Uit de Klei van Saramacca: Een Surinaamse familiegeschiedenis (Amsterdam: Boom, 2019, paper $€ 20.00$ ) is one of the better of the crop. This well-written story of emancipation, warts and all, features the author's parents Nandoe and Trees Sing or Raghoebarsing. It is based on archival research plus the family archives including letters (not all of them very interesting), photos, and official documents. The family history of teacher Trees and tailor Nandoe also gives a good impression of socioeconomomic and political developments in Suriname since the abolition of Indian indenture.

On to fiction: Arend van Dam's De reis van Syntax Bosselman: Verhalen over de slavernij, with illustrations by Alex de Wolf (Amsterdam: Van Holkema \& Warendorf, 2018, cloth €16.99), is a "factional" book on Dutch colonialism, slavery, and abolition in Suriname, and the exposition of 28 Surinamers at the World Expo in Amsterdam in 1883. The clever design of this prize-winning children's book allows it to be read at different levels. It includes the author's personal notes about his exploration of these difficult histories.

Astrid Roemer's Gebroken Wit (Amsterdam: Prometheus, 2019, paper €19.99) is a family history situated between World War II and Suriname's independence. Alternating between Paramaribo and the Netherlands, this complex saga of three generations, featuring the female line, shows how the two countries are inextricably linked through personal ties. Despite the fact that the spelling and punctation are sometimes peculiar, this novel grew on me. Reading it while watching sunrises on the Suriname River may have helped.

Ruben Gowricharn's De prijs van geluk (Soesterberg, the Netherlands: Uitgeverij Aspekt 2019, paper € 22.50) is a novel about Hindostani migration from Suriname to The Hague and the integration of the protagonists in Dutch society. "Migration is a permanent social amputation." In the end, the socioeconomic success of the couple's three children cannot compensate for the emptiness they felt. In conveying this message, the voice of the sociologist sometimes overshadows that of the novelist.

Mireille Geus's Madame Jeanette (Amsterdam: Nw Amsterdam, 2019, paper $€ 20.00)$ is a semi-autobiographical novel on abandonment and Surinamese cooking as therapy. A quick read. 
This year we have received only three books on Curaçao. Landhuizen van Curacao: Juwelen uit het verleden (Willemstad: Stichting Curaçao Style/Volendam: LM Publishers 2019, cloth $€ 45.00$ ) is a magnificent full color coffee table book presenting 78 plantation houses on the island. Michael A. Newton discusses their history and architecture, Carel de Haseth records memories of (previous) inhabitants, and François van der Hoeven looks at the ruins of plantation houses. The main text, describing the history of all surviving mansions, is by Jeannette van Ditshuizen. Also available in English: Plantation Houses of Curaçao: Jewels from the Past.

Three Caribbean Artists: José Maria Capricorne, Nelson Carrilho, Philippe Zanolino, by Marianne de Tolentino, Susan Wilczak \& Monique van Herksen (Volendam: LM Publishers, 2019, paper € 29.50), begins with a brief introduction to Caribbean art and the "Dutch" Caribbean islands and then discusses the magical reality of Capricorne (b. 1932), the art and vision of Carrilho (b. 1953), and the spirituality of Zanolino (b. 196o). Capricorne and Carrilho were born in Curaçao, while French-born Zanolino migrated to the island in 1986. The book includes some 100 illustrations in color.

Eddy Wegman's Photographs of post war Curaçao, 1945-1963 (Volendam: LM Publishers, 2019, cloth $€ 17.50$ ) contains a selection of more than $8 \mathrm{o}$ b/w photos by this amateur photographer, who was born in the Netherlands and left for Curaçao in 1945, to work for the Shell Oil Company. The portraits in particular are forceful.

And finally, one book on the non-Dutch Caribbean. Marcel Catsburg's, Grond zonder rust:Breuklijnen in Haitiaanse bodem (Soesterberg, the Netherlands: Uitgeverij Aspekt, 2019, paper $€ 28.95$ ) is a history of Haiti, inspired by the 2010 earthquake. This well-written account is based on extensive study of literature published in French and English as well as the author's intimate knowledge of the country, where he has lived and worked for five years.

We end this year's Bookshelf by listing information on titles that we have noticed but neither examined nor requested for review-in some cases because their Caribbean content is restricted to a chapter or two, in others because they didn't seem sufficiently compelling given NWIG space limitations, or for a variety of other reasons. Together, they testify to the large number of books being published that at least touch on the Caribbean.

Creole Composition: Academic Writing and Rhetoric in the Anglophone Caribbean, edited by Vivette Milson-Whyte, Raymond Oenbring \& Brianne Jaquette (Anderson SC: Parlor Press, 2019, paper US\$36.oo)

Approaches to Teaching the Works of Edwidge Danticat, edited by Celucien L. Joseph, 
Suchismita Banerjee, Marvin E. Hobson \& Danny M. Hoey Jr. (London: Routledge, cloth US\$140.00)

Chula, by Amanda Alcantara (self-published, 2019, paper US\$14.99) ["an imaginative bilingual collection of intimate poems, short stories, memories and vignettes about the life of a Dominicana before and after moving to the United States"]

Operación Funámbula: Antología personal (1973-2018), by Áurea María Sotomayor (Madrid: Amargord Ediciones, 2019, n.p.) [poetry]

Three Hundred Years of Decadence: New Orleans Literature and the Transatlantic World, by Robert Azzarello (Baton Rouge: LSU Press, 2019, cloth US\$45.00)

The Dictator Novel: Writers and Politics in the Global South, by Magalí Armillas-Tiseyra

(Evanston IL: Northwestern University Press, 2019, paper US\$34.95)

La tinta roja: Estudios sobre literatura de Puerto Rico, by Miguel Ángel Náter (San Juan: Editorial Tiempo Nuevo, 2019, paper US\$40.00)

Hijos del silencio: Ensayos, by José Alcántara Almánzar (San Juan: Isla Negra, 2018, paper n.p.)

Discourses from Latin America and the Caribbean: Current Concepts and Challenges, edited by Eleonora Esposito, Carolina Pérez-Arredondo \& José Manuel Ferreiro (Basingstoke, U.K.: Palgrave Macmillan, 2019, cloth US\$149.99)

News Media Coverage of Environmental Challenges in Latin America and the Caribbean: Mediating Demand, Degradation and Development, edited by Bruno Takahashi, Juliet Pinto, Manuel Chavez \& Mercedes Vigón (Basingstoke, U.K.: Palgrave Macmillan, 2019, paper US\$84.99)

From the Tricontinental to the Global South: Race, Radicalism, and Transnational Solidarity, by Anne Garland Mahler (Durham NC: Duke University Press, 2018, paper US\$27.95)

Caribbean Legion: And Its Mercenary Air Force, 1947-1950, by Dan Hagedorn \& Mario Overall (Warwick, U.K.: Helion and Company, 2019, paper US\$29.99)

Disciplining Coolies: An Archival Footprint of Trinidad, 1846, by Amar Wahab (Berlin: Peter Lang, 2018, paper US\$52.94)

Mother Country: Real Stories of the Windrush Children, by Charlie Brinkhurst-Cuff (London: Headline, 2019, cloth US\$26.99)

Fundador de la República: Federico Pérez Carbó y sus combates por la independencia de Cuba (1855-1901), by José L. Bolívar Fresneda \& Rafael Ángel Simón Arce (n.p.: CreateSpace, 2017, paper US\$29.99)

The Urban Gardens of Havana: Seeking Revolutionary Plants in Ideologized Spaces, by Ola Plonska \& Younes Saramifar (Basingstoke, U.K.: Palgrave Pivot, 2019, cloth US\$59.99)

Waking in Havana: A Memoir of AIDS and Healing in Cuba, by Elena Schwolsky (Phoenix AZ: She Writes Press, 2019, paper US\$16.95)

Last Seasons in Havana: The Castro Revolution and the End of Professional Baseball 
in Cuba, by César Brioso (Lincoln: University of Nebraska Press, 2019, cloth US\$ 29.95)

Cuba Talks: A New Perspective on Cuban Art Now, edited by Laura Salas Redondo \& Jérôme Sans (New York: Rizzoli, 2019, cloth US\$80.00)

Artifacts of the Spanish Colonies of Florida and the Caribbean, 1500-1800: Volume 2: Portable Personal Possessions, by Kathleen Deagan (Washington DC: Smithsonian Books, 2019, cloth US\$6o.oo)

The Caribs of St. Vincent, by Fr. Adrien le Breton S.J. (apparently published in Kingstown, St. Vincent, paper EC\$20.0o) [translation of the 1982 French edition published by the Historical Society of Martinique]

"In the Vortex of the Cyclone": Selected Poems, by Excilia Saldaña (Gainesville: University Press of Florida, 2019, paper US\$19.95)

You Can Cross the Massacre on Foot, by Freddy Prestol Castillo (Durham NC: Duke University Press, 2019, paper US\$22.95)

Civil Society Organisations, Governance and the Caribbean Community, by Kristina Hinds (Basingstoke, U.K.: Palgrave Macmillan, 2019, cloth US\$ 84.99)

Cacicazgos en el Caribe y el continente americano, by Francisco Moscoso (San Juan: Ediciones Puerto, 2019, paper US\$11.95)

Development, Political, and Economic Difficulties in the Caribbean, edited by Ann Marie Bissessar (Basingstoke, U.K.: Palgrave Macmillan, 2019, cloth US\$119.99) [diverse subjects, with seven chapters on Trinidad \& Tobago, the others on various islands] Memoir of a Cocoa Farmer's Daughter: From Caribbean Rural Development Activist to Rural Entrepreneur, by Regina Dumas (Kingston: Arawak, 2018, paper US\$35.00)

Reducing Disaster Risks: Progress and Challenges in the Caribbean Region, edited by Ian Davis, Steve Bender, Fred Krimgold \& Franklin McDonald (London: Routledge, 202O, cloth US\$130.00)

Trésors cachés et patrimoine naturel de la Martinique vue du ciel, by Anne Chopin (photos) \& Patrick Chamoiseau (text) (Paris: HC Editions, 2019, cloth € 28.50) [new edition of a 2007 photo book]

Land, Labour, and Power in a Colonial Catholic Mission in Trinidad, by Maximilian C. Forte (Alert Press [self-published], 2019) 